ESTudos BBEP

\title{
The secret adventures of order: globalization, education and transformative social justice learning*
}

Carlos Alberto Torres

\begin{abstract}
There are many definitions of globalization, or perhaps more accurately, there are many globalizations. Discussing the four faces of globalization - globalization from above, globalization from below, the globalization of human rights, and the globalization of the war against terrorism - and their impacts on education and learning, this article offers an analysis of neoliberal globalization and how "competition-based reforms" affected educational policy in K-12 and higher education. These reforms are characterized by efforts to create measurable performance standards through extensive standardized testing (the new standards and accountability movement), introduction of new teaching and learning methods leading to the expectation of better performance at low cost (e.g., universalization of textbooks), and improvements in the selection and training of teachers. Competition-based reforms in higher education tend to adopt a vocational orientation and to reflect the point of view that colleges and universities exist largely to serve the economic well-being of a society. Privatization is the final major reform effort linked to neoliberal globalization and perhaps the most dominant. As an alternative, the article provides insights into the possibilities of employing the concept of marginality as a central construct for a model of transformative social justice learning. Following the inspiration of Paulo Freire, I argue that transformative social justice learning is a social, political and pedagogical practice which will take place when people reach a deeper, richer, more textured and nuanced understanding of themselves and their world.
\end{abstract}

Keywords: globalizations; neoliberalism; global citizenship; Paulo Freire; theory of marginality; cosmopolitan democracies 


\section{Resumo}

As aventuras secretas de ordem: globalização, educação e aprendizagem para a transformação e justiça social

Existem diversas definições de globalização ou, talvez mais precisamente, pode-se dizer que há muitas globalizações. Ao discutir as quatro faces da globalização - globalização por cima, globalização por baixo, globalização dos direitos humanos e a globalização da guerra contra o terrorismo, - e seus impactos na educação e na aprendizagem, este artigo propõe uma análise da globalização neoliberal e de como reformas baseadas em competição afetaram a política educacional nos Estados Unidos desde o jardim de infância ao ensino médio, e no ensino superior. Essas reformas são caracterizadas por esforços em se criar padrões de desempenho mensuráveis a partir de extensivos testes padronizados (o movimento por novos padrões e "accountability "); pela introdução de novos métodos de ensino e aprendizagem, que trazem a expectativa de um melhor desempenho a um baixo custo (por exemplo, a universalização de livros didáticos); e por melhoras na seleção e no treinamento de professores. Reformas baseadas em competição no ensino superior tendem a adotar uma orientação vocacional e a refletir o ponto de vista de que faculdades e universidades existem largamente para servir ao bem-estar econômico de uma sociedade. A privatização é o esforço final principal por reforma ligado à globalização neoliberal e, talvez, o mais dominante. Como alternativa, o artigo proporciona introspecções às possibilidades de se empregar o conceito de marginalidade como um construto central para um modelo de aprendizagem para a transformação e justiça social. Ao seguir a inspiração de Paulo Freire, defendo que a aprendizagem para a transformação e justiça social seja uma prática social, política e pedagógica que ocorrerá quando as pessoas alcançarem um entendimento mais profundo, rico, com mais texturas e nuances de si próprias e de seu mundo.

Palavras-chave: globalizações; neoliberalismo; cidadania global; Paulo Freire; teoria da marginalidade; democracias cosmopolitas.

\section{Introduction}

The only absolutely certain thing is the future, since the past

is constantly changing. ${ }^{1}$

There are many definitions of globalization, or perhaps more accurately, there are many globalizations. For example, globalization has been defined as "the intensification of worldwide social relations which link distant localities in such a way that local happenings are shaped by events occurring many miles away and vice versa" (Held, 1991, p. 9). Another view sees globalization as "a feature of late capitalism, or the condition of postmodernity, and, more important... the emergence of a world system driven in large part by a global capitalist economy" (Luke; Luke, 2000, p. 287). Others see globalization as the transformation of time
${ }^{1}$ A Yugoslavian aphorism cited by Wallerstein (1999, p. 1). 
and space in which complex interactions and exchanges once impossible become everyday activities (Urry, 1998). And still others see globalization as an assault on traditional notions of society and the nation-state whereby the very nature of citizenship and social change is dramatically altered (Castells, 1997; Touraine, 1988).

In the longue durée, as Fernand Braudel would have put it, globalization processes, as historical facts, have been part of the human adventure almost since its beginnings. ${ }^{2}$ The expansion of the Greek culture and the Roman Empire, the dissemination of the main staples that people grow and consume which have been spread by consumption patterns of specific cultural groups, or the growth and spread of the world's great religions are representative different types of globalization in their own right. The globalizations of AIDS and SARS (Several Acute Respiratory Syndrome) could be considered contemporary manifestations of the great European plague.

In short, with the globalization, we are witnessing a social phenomena which is neither new, nor unique in the way it has percolated social institutions and cultures in the world, and some of the work of Immanuel Wallerstein on world-systems and the transformation of the Mediterranean countries alongside the transformation of capitalism and its impact on the globe detail processes of globalization, which can be traced back to centuries (Wallerstein, 1979, 1980). What perhaps is new in this new wave of globalization is that it entails a simultaneous change in the dynamics by which capital, labor and technology expand, crossing borders with a pace and intensity never seen before, impacting, particularly, on the realm of culture.

With this brief background, it will be important to focus on the many faces of globalization from a political economy perspective, and to outline some of the implications for education. I will not develop, in this article, a substantive analysis of the implications of globalization for culture and mass media, which has been articulated exceedingly well by Raymond Morrow (Morrow, 2003).

\section{The many faces of globalization and the pains of democracy}

${ }^{2}$ The longue durée (in English: the long-term) is an expression used by the French Annales School of historical writing to designate their approach to the study of history, which gives priority to long-term historical structures over events - what François Simiand called histoire événementielle, in English, eventual history - the short-term time-scale that is the domain of the chronicler and the journalist. The longue durée concentrates on all-butpermanent or slowly evolving structures and substitutes for elite biographies, the broader syntheses of prosopography. http://en.wikipedia.org/wiki/ Longue_dur\%C3\%A9e

\author{
If democracy is deliberate delusion, politics is \\ the industry and art of emasculating the truth. \\ (Carlos Alberto Torres)
}

Globalization takes different forms. I would like to call attention to four predominant forms of globalization. One form of globalization, often seen as "globalization from above," is framed by an ideology of neoliberalism and calls for an opening of borders, the creation of multiple regional markets, the proliferation of fast-paced economic and financial exchanges, and the presence of governing systems other than nationstates. Neoliberalism seeks to privatize virtually every process or service 
that can possibly be turned over to private capital. "Selective deregulation" is the motto of this version of globalization.

Another form of globalization represents the antithesis of the first. This form of globalization is often described as "globalization from below," or anti-globalization. Globalization from below is largely manifested in individuals, institutions, and social movements, actively opposed to that which is perceived as corporate globalization. For these individuals and groups, the motto is "no globalization without representation."

There is a third form of globalization, which pertains more to rights than to markets - the globalization of human rights. With the growing ideology of human rights taking hold in the international system and in international law, many traditional practices endemic to the fabric of particular societies or cultures (from religious to esoteric practices) are now being called into question, challenged, forbidden, or even outlawed. The advancement of cosmopolitan democracies and plural citizenship is the theme of this version of globalization.

There is a fourth manifestation of globalization. This form extends beyond markets, and, to some extent, is against human rights. It is the globalization of the international war against terrorism. This new form of globalization has been prompted in large part by the events of September $11^{\text {th }}$ - which were interpreted as the globalization of the terrorist threat - and the reaction of the United States to the event. The anti-terrorist response has been militaristic in nature, resulting in two coalition wars led by the U.S. against Muslim regimes in Afghanistan and Iraq. Yet, the overall theme of this process was not only its military flavor, but also the emphasis on security and control of borders, people, capital, and commodities - that is, the reverse of open markets and highpaced commodity exchanges suggested by neoliberalism. Security as a precondition of freedom is the theme of this form of globalization.

\section{Globalization and its impact on K-12 and higher education}

... politics and fiction are thrown together and pick each other's pockets, they are separate universes, irreconcilable and symmetrical.

(Jorge Luis Borges, interviewed by Ricardo Piglia in Cuadernos de Recienvenido)

There are many impacts of globalization on educational policy. While I have defined four faces of globalization, in this short article, I will concentrate on the first two, globalization from above and globalization from below.

\section{Globalization from above}

Agencies, multilateral or bilateral institutions, such as the World Bank, the International Monetary Fund (IMF), some agencies of the 
United Nations, including the United Nations Educational, Scientific, and Cultural Organization (Unesco), and perhaps the Organization for Economic Cooperation and Development (OECD) have promoted a model of neoliberal globalization (Teodoro, 2003).

The neoliberal agenda includes a drive towards privatization and decentralization of public forms of education, a movement toward educational standards, a strong emphasis on testing, and a focus on accountability. With regard to accreditation and universalization, major efforts are underway throughout the world to reform academic programs through accreditation processes and various strategies that produce increased homogeneity across national boundaries.

Reforms associated with international competitiveness are akin to what Carnoy (2001) described in the K-12 sector as "competition-based reforms". These reforms are characterized by efforts to create measurable performance standards through extensive standardized testing (the new standards and accountability movement), introduction of new teaching and learning methods, leading to the expectation of better performance at low cost (e.g., universalization of textbooks), and improvements in the selection and training of teachers. Competition-based reforms in higher education tend to adopt a vocational orientation and to reflect the point of view that colleges and universities exist largely to serve the economic well-being of a society.

Privatization is the final major reform effort linked to neoliberal globalization, and perhaps the most dominant. Neoliberal economic supporters view the marketplace as the ideal regulator of services, products, and costs. Consequently, if we think of education as a product or service, then from a neoliberal perspective, the best way to regulate education is to allow the market to do so. Nation-states need not fund or concern themselves with tuition costs; the market can take on such responsibilities quite handily. If institutions price themselves too highly, prospective students will respond by selecting other less costly institutions. The system is, from the perspective of neoliberalism, entirely just, given that subjective individuals do not open and close doors, but a system of costs and payments dictates nearly every outcome.

It has been argued that "globalization has had a major impact on education through the finance-driven reforms promoted by international institutions" (Carnoy, 1999, p. 51). The privatization of higher education in debt-ridden countries such as Mexico, Brazil, and Argentina typically is advanced by the IMF and the World Bank as a pre-condition to further lending to these countries. A precondition of such lending involves the transfer of educational financing from higher education to lower levels of education - under the premise that to subsidize higher education is to subsidize the rich, since the majority of students enrolled in higher education are from the middle classes and from affluent families. Privatization has advanced hand in hand with increased entrepreneurialism, especially in the most developed countries, as universities have sought to expand their revenue through a variety of profit-seeking endeavors, 
including satellite campuses and extension programs around the world.

In closing this section, it is important to emphasize that privatization policies are crucial elements of the reforms oriented toward promoting open markets, and, as such, they are important policy tools of neoliberalism. Two key benefits are seen by neoliberals: (1) the pressure of fiscal spending is reduced by the privatization of public sector enterprises, and (2) privatization is a powerful instrument for depoliticizing the regulatory practices of the state in the area of public policy formation. Therefore, the underlying philosophy of "finance-driven reforms may contribute to the shortage of public resources for education with net gains for economic growth" (Carnoy, 1999, p. 52).

However, as the last two decades have made clear, the implications of privatization and the push for market policies to limit the state's role in social sectors pose serious problems: "In the context of the market forces, the state's interventionist role is likely to decline. This will have implications for all categories of people who, by virtue of their already weak position in spheres of knowledge, skills, access to goods and services, and control over resources, need some protective legislation and provisions. Left to themselves in the open market, their situation is likely to further deteriorate" (Kaur, 1999, p. 126).

\section{Globalization from below}

The anti-globalization movements see a system based entirely on costs and payments as harsh and cruel. Individuals are not born into the same economic or class standing, and consequently governments acting in the name of the public good must intervene to create systems and processes that extend beyond the arbitrary rationale of economic determinism. The challenge that anti-globalization forces are confronting with is the degree to which global economic systems and social relations are being constructed by neoliberals.

In the 1990s diverse groups have been brought together under the banner of anti-globalization, including groups opposed to corporate capitalism, but also environmentalists, unions, and even nationalistic isolationists, such as Pat Buchanan's followers in the U.S. The isolationists are worried about NGOs replacing national governments and fear, in the case of the U.S., that their own country will lose its global dominance and its citizens their economic privilege. But the primary theme of "globalization and its discontents" concerns the establishment of a set of rules governing the global economy and whose interests those rules serve (Stiglitz, 2002).

The anti-globalization movements argue positions focused on social justice and equality. These movements have had a variety of important dissident voices. For example, starting with Seattle in 1999, world summits such as the September 2000 IMF-World Bank summit in Prague, and the July 2001 G-8 meeting in Genoa have taken place amid a chorus of 
critics reacting to the closed nature of global decision making. Outspoken individuals and groups include former Pope John Paul II, and the Catholic Church, various Protestant churches, feminist groups, environmental groups such as Greenpeace, indigenous rights groups, and communist, socialist, anarchist, and libertarian groups. There is a multiplicity of opposition groups, which is vast and growing in number and degree of discontent (Rhoads, 2003; Stiglitz, 2002).

The rich array of worldwide anti-globalization views and actions has found sources of support within the academy, in part because colleges and universities also have come under the influence of global processes, and at times seem as disempowered as those groups and individuals taking to the streets in Seattle, Prague, and Genoa. The meetings of the G-8 nations are becoming increasingly more difficult to organize with the growing opposition of social movements and their active challenge to the world economic powers.

The reaction to worldwide growing inequality, the dominance of financial sectors, which are seen as responsible for the greatest economic collapse of our generation, and the deleterious outcomes of the multiple globalization processes have brought together a number of social movements, which are challenging capitalism as much as the established political powers. Hence, various social movements in their particular locales, for instance, the Occupy Movement in New York, Los Angeles, and the most important cities in the US, the Landless Workers' Movement in Brazil, the factory occupation movement in Argentina, and the Indignados Movement in Western Europe are good examples of this renewed counter-hegemonic energy (Bryne, 2012; Carroll, 1997; Mayo 2005; Torres, 2009; Walter, 2007).

Students have also been actively engaged in anti-globalization protests at meetings of global trade organizations and world leaders. They were well represented in the massive WTO protests in Seattle in December 1999. These groups reject the notion that globalization is the natural outcome of contemporary economic relations and; instead, believe that powerful economic organizations create the climate and context for neoliberal globalization. Regarding K-12 education in Latin America, there have been large teachers' protests in Argentina, Costa Rica, Chile, Guatemala, Mexico, etc. The interests of some of these groups lead us to consider another manifestation of globalization, one that is not so much a counter movement as it is a movement for improving the human condition.

\section{Globalization of human rights}

The presence of another form of globalization centered on advancing human rights poses, in itself, another round of issues to be addressed. The movement toward universal human rights is a powerful force that pushes us beyond conversations about certain rights being merely "a good idea to what which ought to be the birthright of every person" 
(Bunch, 2001, pp. 138-139). The idea of global human rights has also become a central issue in considering citizenship and democracy. Soysal (1994) and Torres $(1998,2009)$ analyze the limits of citizenship in the era of globalization and highlighted some of the issues. Nuhoglu Soysal argues that "the logic of personhood supersedes the logic of national citizenship [and] individual rights and obligations, which were historically located in the nation-state, have increasingly moved to a universalistic plane, transcending the boundaries of particular nation-states" (Soysal, 1994, pp. 164-165). Soysal went on to discuss the idea of "cosmopolitan democracies," or transnational political systems, relatively divorced in their origin and dynamics from nation-states.

If the agenda for human rights is reconfiguring the boundaries of nations and the individual rights of citizens, and these are seen as preconditions for attaining basic equality worldwide, then educational systems will need to confront the tension between human rights as a globalized project of cosmopolitan democracies, and the long-standing influence of nationalism. This tension is also projected in questions of identity and whether the particular rights of cultural and religious groups will be upheld in the face of an ideology of global human rights (Torres, 1998, 2003a, 2009a, 2009b).

Key concerns of global human rights advocates center largely on the universal rights to food, water, and health care. Others suggest that the right to participate in a society's governance structure and the right to a quality education also ought to be universal. In terms of the latter two rights, schools and universities become key sites of struggle, as concerns about what constitutes "quality" and the role that educational institutions play in shaping expectations and dispositions relative to civic participation come to the forefront. Teachers' Unions have played major roles in this struggle (Torres et al., 2013).

A key concern specifically tied to higher education is the question of whether education is a privilege or a right. This has become a major point of contention in countries, such as, Mexico and Argentina, where structural adjustments clearly situate participation in higher education as a privilege, while long-standing social contracts within these two countries suggest otherwise. Here, we see a clear clash of two oppositional agendas, one focused on privatization and advancing a competition-based social structure, and the other focused on social intervention and advancing a spirit of collectivism (Torres; Puiggrós, 1996; Rhoads; Torres, 2006).

\section{Globalization of the international war against terrorism}

The most obvious change in the process of globalization in the last few years was brought about by the terrorist attack of September, $11^{\text {th }} 2001$, which undermined the invincibility of the United States, never before attacked in its continental territories. In waging a relentless counterassault against the Taliban and Al-Qaida, and a second war against Iraq, 
the U.S. has produced massive change at a global level. In combination with the continuing reverberations of September 11, American antiterrorist initiatives continue to transform global relations in the spheres of economics, politics, culture, and education (Apple, 2002).

The consequences of the 9/11 attacks, and the ensuing global war against terrorism have important consequences for an increasingly interconnected world. Let us look at the impact on higher and K-12 education. One consequence is the restrictive climate for scholars and students seeking transnational mobility. This phenomenon, of course, is most notable in the United States, where political and social pressure to ensure domestic security has led to more highly regulated and monitored borders and points of entry. A concern for many universities is the availability of international education for foreign students - not a minor source of income for countries heavily involved in international education.

In addition to possible financial reverberations associated with international education, there are concerns about limitations placed on scholarly exchange and the general assault on academic freedom. I focus my analysis on the U.S., but it is important to note that the impact extends to the global intellectual arena. A key threat to academic freedom centers on the U.S. government's demand on colleges and universities to track foreign students and some professors through a computerized system known as the Student and Exchange Visitor Information System, or Sevis.

The government requires that colleges and universities keep track of who is admitted and hired from a foreign country and when they enter and leave the country. This requirement creates a situation in which members of a particular academic community are expected to monitor the movement of other members of the same academic community, creating an atmosphere of mistrust. Foreign students and professors are full members of the same academic community that is now expected to monitor their coming and going. The responsibility for managing Sevis is more likely to fall on staff at international centers campus than not. Consequently, instead of providing academic and cultural support, staff may be just as likely to be engaged in information management for the U.S. government, all in the name of the "new militarism" aimed at fighting global terrorism.

\section{The secret adventures of order: transformative social justice learning in the context of globalizations}

In a century that adored the chaotic idols of blood, land and passion, he always preferred the lucid pleasures of thought and the secret adventures of order. (Jorge Luis Borges, on Valery)

To deal with all these faces of globalization, and to analyze the implications for education is no easy feat. Likewise, to explore the limits 
and possibilities of a model of transformative social justice learning in the context of globalization, and the challenges to education require not only acumen, but theoretical sophistication and steel political will.

Having devoted two books to analyze some alternatives, both theoretically and politically, to neoliberal globalization (Torres, 2009a, 2009b), and having offered a set of hypothesis of how to analyze and challenge the new neoliberal common sense in higher education (Torres, 2011), in this conclusion, I will limit myself to reflect upon a model of transformative social justice learning in the context of multiple globalizations.

I argue that transformative social justice learning is a social, political and pedagogical practice which will take place when people reach a deeper, richer, more textured and nuanced understanding of themselves and their world. Not in vain, Paulo Freire always advocated the simultaneous reading of the word and the world. Based on a key assumption of critical theory that all social relationships involve a relationship of domination, and that language constitutes identities, transformative social justice learning, from a meaning making or symbolic perspective, is an attempt to recreate the various theoretical contexts for the examination of rituals, myths, icons, totems, symbols, and taboos in education and society, an examination of the uneasy dialectic between agency and structure, setting forward a process of transformation (Torres, 2003b). From a sociological perspective, transformative social justice learning entails an examination of systems, organizational processes, institutional dynamics, rules, mores, and regulations, including prevailing traditions and customs, that is to say, key structures, which by definition reflect human interests.

In examining the implications of globalization for education, how can progressive scholars take advantage of transformative social justice learning as a methodology and theory of social transformation? Let me be bold: one may argue that this model of transformative social justice learning is a social construct, which becomes marginal in the context of contemporary social politics. Indeed, those who practice this approach are, by definition, marginal to the overall dynamics of political struggle, and to the processes of institutional development, in academia and elsewhere.

Politically, one may need to understand that marginality is not being an outsider, but it constitutes a form of insertion in the context of the global debate and struggle for social justice. The notion of marginality became; thus, a central notion to pursue transformative social justice learning. Progressive scholars pursue this approach even if we know that we are marginal to the central concepts and practices of the liberal and conservative establishments, which seem to be, in education at least, poised to emphasize the need to improve cognitive learning through the movement of testing, or accountability in schools.

The idea of marginality doesn't rest simply on notions of opposition or negativity against the positivism, and on the positivity of the pedagogical, 
political, and epistemological models that predominate in academy and social life. We cannot accept our marginality predicated just on the difficulties that we face, or in the losses that we endure in this long haul, this longe durée of social struggles. We shall also celebrate, within the notion of marginality, the different triumphs that we have in our struggles. We cannot criticize without celebrating.

The notion of marginality is predicated resorting to a historical nuanced analysis of the dynamics between social agencies and structures, and to a refined conceptual understanding, which draws on the strengths of Critical Social Theory (Morrow; Torres, 1995). The notion of marginality is both a model of advocacy, with important normative implications, and an analytical model with clear political objectives. Remember Freire's dictum, we teach against somebody, and on behalf of somebody, on behalf of some values, and against some values. Therefore, Paulo Freire defended the politicity of education, which is a central tenet of marginality as an epistemological, political, and even spiritual position in education.

Marginality is an invitation to a struggle in the long haul, linking theory and praxis, not only as an individual, but also as a social movement perspective. In doing so, a notion of marginality, and marginal voices that reclaim to be heard in the debates, point to the importance of structures to help agencies. Thus, reclaiming the transformative role of Teachers' Unions and social movements in the context of public education is part and parcel of a political program of struggle.

Marginality as a political and practical option challenging neoliberal globalization draws on a model of spirituality that is clearly utopian and utopist. It is utopian because utopia is like a distant horizon that one wants to reach, but never does. One walks two steps to reach it, and it moves two steps farther. One walks two more steps, and the horizon moves two steps farther away. What is, then, the advantage of utopia as a political rationale and spiritual endeavor? It helps us to walk.

Hence, progressive scholars draw not only on utopian, but also on utopist models. Critical educators want to examine the different and alternative models of society, the utopist models, the different social construction that are emerging in this walking toward the future. Make no mistake, even the same notion of neoliberalism is a utopist model, a la par, for instance, to the model of Leninism, another utopist model of the good society.

If democracy is deliberate delusion and politics is the industry and art of emasculating the truth, marginality became both an antidote to the ills of democracy, and a suggestive methodological approach based on the principle of uncertainty. A principle that is very important as an epistemological stand point, so well developed by Nobel Prize Illya Prigigoni. Only this way can be achieved what many scholars, including Bernan Morris, so aptly termed the "re-enchantment of the world." 


\section{References}

AMMASH, H. S. Toxic pollution, the Gulf War, and sanctions. In: ARNOVE, A. (Ed.). Iraq under siege: the deadly impact of sanctions and war. Cambridge, MA: South End Press, 2002. p. 205-214.

APPLE, M. W. Patriotism, pedagogy, and freedom: on the educational meanings of September $11^{\text {th }}$. Teachers College Record, v. 104, n. 8, p. 1760-1772, 2002.

BIRCHARD, K. Canadian students hold nationwide protests over tuition increases. The Chronicle of Higher Education, 2002.

BOLLAG, B. A Cuban scholar shut out. The Chronicle of Higher Education, p. A16-A18, 2003.

BOYER, R.; SAILLARD, Y. Regulation theory: the state of the art. New York: Routledge, 2002.

BRENDER, A. 74 universities in Japan hope to open graduate-level law schools. The Chronicle of Higher Education, 2003.

BRYNE, J. (Ed.). The occupy handbook. New York: Back Bay Books, 2012.

BUNCH, C. Women's human rights: the challenges of global feminism and diversity. In: DEKOVEN, M. (Ed.). Feminist locations: global and local, theory and practice. Piscataway, NJ: Rutgers University Press, 2001. p. 129-146.

CARNOY, M. Globalization and educational reform: what planners need to know. Paris: Unesco, 1999.

CARNOY, M. El impacto de la mundialización en las estrategias de reforma educativa. Revista de Educación, n. extraordinario, p. 101-110, 2001.

CARROL, W. K. (Ed.). Organizing dissent: contemporary social movements in theory and practice. $2^{\text {nd }}$ ed. Toronto, Canada: Garamond, 1997.

CASTELLS, M. The power of identity. Boston: Blackwell, 1997.

CHOMSKY, N. Profit over people: neoliberalism and global order. New York: Seven Stories Press, 1998.

DEL CASTILLO, D. Afghan government backs plan for an Americanstyle university in Afghanistan. The Chronicle of Higher Education,

2003a. 
DEL CASTILLO, D. American colleges are offered grants to aid in revival of Iraqi higher education. The Chronicle of Higher Education, 2003b.

DEL CASTILLO, D. Publishing house criticizes U.S. government for arrest of Iraqi scientist on "most wanted" list. The Chronicle of Higher Education, 2003c.

DEWEY, J. Democracy and education. New York: The Free Press, 1916.

FAY, B. Critical social science: liberation and limits. Ithaca, NY: Cornell University Press, 1987.

FOUCAULT, M. The archaeology of knowledge \& the discourse on language. New York: Pantheon Books. 1972. (Original work published in 1969).

FOUCAULT, M. Power/knowledge: selected interviews and other writings 1972-1977. New York: Pantheon Books, 1980.

FREIRE, P. Pedagogy of the oppressed. New York: Continuum. 1970. (Original work published in 1968).

FRIEDMAN, A. Microregulation and post-Fordism: critique and development of regulation theory. New Political Economy, v. 5, n. 1, p. 59-76, 2000.

GIROUX, H. A. Theory and resistance in education: a pedagogy for the opposition. New York: Bergin G Garvey, 1983.

HABERMAS, J. Theory and practice. Boston: Beacon Press. 1974. (Original work published in 1971).

HELD, D. (Ed.). Political theory today. Stanford, CA: Stanford University Press, 1991.

HORKHEIMER, M. Critical theory: selected essays. New York: Continuum. 1972. (Original work published in 1968).

KAUR, M. Globalization and women: some likely consequences. In: SETHI, R. Mohini (Ed.). Globalization, culture and women's development. Jaipur, India: Rawat, 1999. p. 119-128.

LIN-LIU, J. Unesco plans transnational quality-assurance effort for academe. The Chronicle of Higher Education, 2001.

LUKE, A.; LUKE, C. A situated perspective on cultural globalization. In: BURBULES, N. C.; TORRES, C. A. (Ed.). Globalization and education: critical perspectives. New York: Routledge, 2000. p. 275-297. 
MARCUSE, H. Studies in critical philosophy. London: New left Books, 1972.

MAYO, M. Global citizens: social movements \& the challenge of globalization. London: Zed Books, 2005.

MORROW, R. Globalization and culture. 2003. Unpublished manuscript.

OLMOS, L. E.; VAN HEERTUM, R.; TORRES, C. A. (Ed.). In the shadows of neoliberal globalization: educational reform in the last 25 years in comparative perspective [E-book]. Oak Park, IL: Bentham Science, 2011.

RHOADS, R. A. Globalization and resistance in the United States and Mexico: the global Potemkin village. Higher Education, v. 45, n. 2, p. 223-250, 2003.

RHOADS, R. A.; MINA, L. The student strike at the National Autonomous University of Mexico: a political analysis. Comparative Education Review, v. 45, n. 3, p. 334-353, 2001.

RHOADS, R. A.; TORRES, C. A. (Ed.). The university, state and markets: the political economy of globalization in the Americas. Stanford: Stanford University Press, 2006.

RHOADS, R. A.; VALADEZ, J. R. Democracy, multiculturalism, and the community college: a critical perspective. New York: Garland, 1996.

SIDHU, R. Selling futures to foreign students: global education markets. 2003. Unpublished manuscript.

SLAUGHTER, S.; LESLIE, L. L. Academic capitalism: politics, policies, and the entrepreneurial university. Baltimore: Johns Hopkins University Press, 1997.

SOYSAL, Y. N. Limits of citizenship: migrants and postnational membership in Europe. Chicago: University of Chicago Press, 1994.

STIGLITZ, J. E. Globalization and its discontents. New York: Norton, 2002.

TEODORO, A. Educational policies and new ways of governance in a transnationalization period. In: TORRES, C. A.; ANTIKAINEN, A. (Ed.), The international handbook on the sociology of education: an international assessment of new research and theory. Lanham, MD: Rowman \& Littlefield, 2003, p. 183-210.

TIERNEY, W. G. Building communities of difference: higher education in the 21st century. Westport, CT: Bergin \& Garvey, 1993. 
TIERNEY, W. G.; RHOADS, R. A. Postmodernism and critical theory in higher education: implications for research and practice. In J. C. Smart (Ed.), Higher education: handbook of theory and research. New York: Agathon Press, 1993. p. 308-343.

TORRES, C. A. Democracy, education, and multiculturalism: dilemmas of citizenship in a global world. Lanham, MD: Rowman \& Littlefield, 1998.

TORRES, C. A. Globalization, education, and citizenship: solidarity versus markets? American Educational Research Journal, v. 39, n. 2, p. 363-378, 2002.

TORRES, C. A. Globalizations and education. Paper presented at the meeting of the Fondazione Liberal, Milan, Italy, 2003.

TORRES, C. A. Paulo Freire, education and transformative social justice learning. Paper presented at the Fifth International Conference on Transformative Learning, New York, 2003b.

TORRES, C. A. Education and neoliberal globalization. New York: Routledge, 2009a.

TORRES, C. A. Globalizations and education: collected essays on class, race, gender, and the state. New York: Teachers College Press, 2009b.

TORRES, C. A. Public universities and the neoliberal common sense: seven iconoclastic theses. International Studies in Sociology of Education, v. 21, n. 3, p. 177-197, 2011.

TORRES, C. A.; MORROW, R. Social theory and education: a critique of theories of social and cultural reproduction. Albany, New York: State University of New York Press, 1995.

TORRES, C. A.; NOGUERA, P. (Ed.). Social justice education for teachers: Paulo Freire and the possible dream. Rotterdam, The Netherlands: Sense, 2008.

TORRES, C. A.; PUIGGRÓS, A. (Ed.). Education in Latin America: comparative perspectives. Boulder, CO: Westview Press, 1996.

TORRES, C.A et al. Teachers' unions, the capitalist state and the contradictions of educational reform. Spirale Revue de Recherches en Education, n. 51, p.133-140, jan. 2013.

TOURAINE, A. Return of the actor: social theory in postindustrial society. Minneapolis, MN: University of Minnesota Press, 1988. 
URRY, J. Contemporary transformations of time and space. In: SCOTT, P. (Ed.). The globalization of higher education. Buckingham, UK: Open University Press, 1998. p. 1-17.

WALLERSTEIN, I. The capitalist world-economy. Cambridge, UK:

Cambridge University Press, 1979.

WALLERSTEIN, I. The modern world-system II: mercantilism and the consolidation of the European world-economy, 1600-1750. New York: Academic Press, 1980.

WALLERSTEIN, I. A left politics for the $21^{\text {st }}$ century? Or, theory and praxis once again. Binghamton, NY: Binghamton University, Fernand Braudel Center, 1999.

WALTER, P. Adult learning in new social movements: environmental protest clayoquot sound rainforest. Adult Education Quarterly, v. 57, n. 3, 2007, p. 248-263.

Carlos Alberto Torres is a professor of education in the Social Science and Comparative Education Division at the University of California-Los Angeles (UCLA) and founding director of the Paulo Freire Institute in São Paulo.

catnovoa@aol.com

Article received on 15 may 2013.

Article accepted on 20 august 2013. 